\title{
Geo-Strategic Imperative of North-Western Border: Triangular Region Kalapani - Lipulekh and Limpiadhura of Nepal
}

\section{Bharat Khanal}

\begin{abstract}
The extreme north western region of Nepal is bordered with India and China and separated by Mahakali River. As per Article 5 of Sugauli treaty and various other evidences like, historical facts, ancient maps, river science, government correspondence and other documents proves that the river originating from Limpiadhura form the international boundary between Nepal and China. However, the certain parts of Nepalese territory have been under the control of India from seven decades. Owing to the historical and geographical proximity, Nepal has maintained special relations with her immediate neighbors, India and China, despite several complex situations. Remaining away from strategic competition and rivalry; and gaining maximum benefit from India and China as they are global and regional players would best serve the national interest of Nepal. Underdeveloped nature of physical infrastructures, nascent institutional structures and poor presence of government machinery in the North western border of Nepal has complicated the problem. Our neighbors should be sensitive and respectful to our concerns and interests. Delicate handling of border issues is in our interest. Nepal has become the center of geopolitical interest in the present world.
\end{abstract}

Sands of geopolitics are constantly shifting in South Asia and Nepal cannot remain aloof from it. Influence in Nepal from competition and cooperation is rising. There is a need of cooperation for transit economy and trilateral cooperation. Nepal should use her diplomatic expertise and regain our territory by maintaining friendly and harmonious relations with her neighbors. Nepal and India shouldn't delay in resolving such outstanding disputes. Both countries should bring their evidences and carefully examine that evidence by creating a favorable negotiating environment. Above all, national consensus on such sensitive issue is important.

Keywords: Geo strategic, border, security, foreign policy, diplomacy, neighbor, dialogue

\section{Introduction}

Nepal shares $1880 \mathrm{Km}$ long historical, open, unregulated and complicated border with India and $1414 \mathrm{Km}$ long border with Tibet; an autonomous region of Peoples Republic of China. Nepal and India are destined by geography, civilization and traditional linkages. According to the Article 5, of Sugauli Treaty 1816 A.D. concluded between East India Company and Nepal, the King of Nepal gave up his claims over the region west of the river Kali which originates in the high Himalayas and flows into the great plains of 
Indian sub-continent. Sugauli Treaty is not a matter of pride for Nepal as she has to lose one third of its present territory after the conclusion of this treaty and Nepal had to forcefully sign it. According to the Treaty, the British rulers recognized Nepal's right to region that fell to the East of river Kali ${ }^{1}$. More than a 370-square-kilometre strip located at the north-western corner of the country has been under Indian administration for a long time. ${ }^{2}$ It said that the course of the Kali River, called the Mahakali downstream, marked Nepal's western boundary which is the subject of the current dispute. India says the Kali starts at Lipulekh, and Nepal says Limpiyadhura is the river's source. The long Indian presence in the area, the national security importance India attaches to the area, and the neglect by Nepali rulers for nearly 200 years to claim what rightfully belonged to Nepal has added to the complexity of the problem.

National security means complete safeguarding of a country in geographical, social, economical and political perspectives. Each country has identified the matters of its national aspirations and of vital national interests based on its fundamental norms and values. ${ }^{3}$ Perhaps no country other than Nepal has accumulated the matchless experience on how difficult it is to

1 Kallol, B. (2020, May 24) Why Are Nepal India Fighting Over Kalapani. The Hindu. Retrieved from https://www.thehindu.com/news/national/ why-are-india-and-nepal-fighting-over-kalapani/ article31660401.ece

2 Koirala, N. (2020, June 4). Limpiadhura-LipulekhKalapani dispute. The Kathamandu Post. Retrieved from https://kathmandupost.com/columns/2020/06/04/ limpiyadhura-kalapani-lipulekh-dispute

3 National Secuity Policy 2016, section 1.2.2, Page 3. Retrieved from Law Books Management Board, Babarmahal Kathmandu. be squeezed in between two big powers. ${ }^{4}$ Due to internal political upheavals and frequent regime change the border dispute at the North-Western region didn't get momentum. But the issue of Kalapani was always at the hearts and minds of every Nepali. Every Nepali is well aware of the fact that Kalapani and the surrounding region is our land and we will get it sooner or later.

The 1950 treaty of Peace and Friendship between Nepal and India and the 1947 Tripartite Treaty between Nepal, India and the United Kingdom connects the two nations with a special relationship, perpetual peace and friendship, mutually recognized and respected sovereignty, territorial integrity and independence of each other, people to people relationship, open border to move freely, live and work in either country and the Nepalese Gurkhas fighting for the dignity, sovereignty and territorial integrity of India. ${ }^{5}$ India and Nepal is probably the closest neighbor's in existence anywhere who share the greatest number of differences. ${ }^{6}$ We should not let our territory being used at the interest of other.

Ever since the unification of Nepal by P. N. Shah, the notion of "am between Two Boulders" has remained a guiding principle in our foreign policy. In 1991, Nepal formally raised the border issue with India, and a technical committee was formed to resolve it. The panel identified several areas with contested claims and resolved 90 percent of them.

4 Rai, A.B (Ed. 2010). Nepal's Foreign Policy: Historical outline and Future Perspective International Relations and Foreign Affairs: Sopan Monthly.

5 Basnyat, Binoj. (2020). Nepal on A Larger Geopolitical Modification In The Himalayas. Retrieved From https://www.spotlightnepal.com/2020/06/14/ nepal-larger-geopolitical-modification-himalayas/ 6 Subedi, S. (2005). Dynamics of Foreign Policy and Law: A Study of Indo-Nepal Relations: Oxford Publications. 
"Foreign policy is determined by geography or physical conditions and responsible foreign policy remain rational and predictable. National interest doesn't change, even if there is a change in the government". ${ }^{7}$ According to Article 5 of the Constitution of Nepal, border security shall be the basic element of national interest and any act contrary to the national interest shall be punishable by the law. As per the article 52 of the same Constitution, it shall be the obligation of the state to keep intact the freedom, sovereignty, territorial integrity and independence of Nepal. As per the article 50(4) of the Constitution, the State shall direct its international relations towards enhancing the dignity of the nation in the world community by maintaining international relations on the basis of sovereign equality, while safeguarding the freedom, sovereignty, territorial integrity and independence and national interest of Nepal. ${ }^{8}$ The only option Nepal has to try and resolve the issue through quiet diplomacy, through dialogue and forming Indian public opinion in our favor. This requires leadership with a very high moral standing; sensitivity, international respect, statesmanship, and an ability to communicate complex issues openly, politely, respectfully, and with firmness. ${ }^{9}$ We have to manage our internal order which we have failed to manage.

7 Asian Institute of Diplomacy and International Affairs (AIDIA) (2016). Revisiting Nepal Foreign Policy on Contemporary Global Power Structure. Retrieved from file://C:/Users/lenovo/Downloads/ AIDIA.pdf

8 The Constitution of Nepal, Article 50(4). Retrieved from https://www.mohp. gov.np/downloads/Constitution $\% 20$ of $\% 20 \mathrm{Nepal} \% 202072$ full_english.pdf

9 Koirala, N. (2020, June 4). Limpiadhura-LipulekhKalapani dispute. The Kathamandu Post. Retrieved from https://kathmandupost.com/columns/2020/06/04/ limpiyadhura-kalapani-lipulekh-dispute

\section{Methodology}

Effort has been made to identify current strategic challenges from external as well as internal dimension. The article is prepared with the information from secondary sources as books, reports and articles, and those that are qualitative in nature. Therefore, descriptive and explanatory research designs are used in this article. Qualitative information is honestly presented and interpreted by using contextual analysis methods. This paper is prepared with the writer's personal understanding and personal judgment in the related field. Through the review of the various literatures and going through expert's opinion in the border issue, various alternatives for the solution have been drawn.

Analysis of the Border Dispute in the North-Western Border of Nepal

\section{a. North -Western Nepal: East of Kalapani River}

Article 5 of Sugauli Treaty 1816: The Rajah of Nepal renounces for himself, his heirs, and successors, all claims to or connexion with the countries lying to the west of the River Kali and engages never to have any concern with those countries or the inhabitants there of. The North Western boundary of Nepal is demarcated from the above provision. No amendment to Sugauli

\section{Treaty has been Made so far}

The Government of Nepal has consistently maintained that as per the Sugauli Treaty (1816), all the territories east of Kali (Mahakali) River, including Limpiyadhura, Kalapani and Lipu Lekh, belong to Nepal. ${ }^{10}$ It may be recalled that the Government of Nepal had expressed its disagreement in 2015 10 Retrieved from https://mofa.gov.np/press-releaseregarding-lipu-lekh/. 
through separate diplomatic notes addressed to the governments of both India and China when the two sides agreed to include Lipu Lekh Pass as a bilateral trade route without Nepal's consent in the Joint Statement issued on 15 May 2015 during the official visit of the Prime Minister of India to China. ${ }^{11}$ Also, neither of the countries consulted Nepal or took its opinion before that agreement that enhances the pilgrimage and trade to Tibet. Therefore, it is necessary for both countries to commit themselves to ushering IndoNepal relations into a new era of cooperation based on the generally accepted principle of international law, the tenets of non alignment, and principles of equality and mutual respect for each other's vital national interest. ${ }^{12} \mathrm{We}$ have to find the satellite image of Kali River because satellite image can't be changed. Although map was not attached to the Treaty but article 5 of Sugauli Treaty has clearly stated that Mahakali River is the border river between two countries.

\section{b. A Bone of Contention}

On November 2, 2019 Government of India released a political map that included the disputed territory of Nepal. On May 8, 2020 Indian Defense Minister inaugurated the 80 $\mathrm{Km}$ road that crosses the Nepalese territory. Nepal Government requested twice for a dialogue via diplomatic notes but there was no response from the Indian side. This shows that Indian Government turned a deaf ear to Nepal's diplomatic request. Nepal was compelled to release its revised political and administrative map which incorporates Limpiyadhura, Lipu Lekh and Kalapani, the

11 Retrieved from https://mofa.gov.np/press-releaseregarding-lipu-lekh/.

12 Subedi, S. (2005). Dynamics of Foreign Policy and Law: A Study of Indo-Nepal Relations: Oxford Publications. territories encroached upon by India. Nepal has included $335 \mathrm{sq} \mathrm{km}$ of land in the map. With this, Nepal has now an area of 147,516 sq $\mathrm{km}$. According to the earlier version of Nepal's map, officially issued in 2032 BS, it covered an area of $147,181 \mathrm{sq} \mathrm{km} .{ }^{13}$ further; new map is officially used in all government communications. The new map issued by Nepal has been passed by the parliament. Publication of the map was an effective strategy that Nepal had carried out.

Nepal had a diplomatic rift with neighbor at the time when the whole world is badly hit by Corona Pandemic. India has always claimed that Kalapani is disputed territory, despite accepting this fact she never stops unilateral construction of infrastructure in that area. We were using the maps published from other countries due to dearth of experts, lack of resources in survey field. So, we were unknowingly using the wrong maps in our official use. It was due to lack of our publishing capacity. Due to remote access to disputed area it has remained insignificant for a long. The Nepal-China Boundary protocol of January 20, 1963 established permanent boundary markers as numbered 1 to 79 in serial order from east to west. The first marker of the Nepal -China border is at the Tinker. From 1979-80, the Indo-Tibetan Border Police (ITBP) has been manning the boundaries. Indian troops have been manning the disputed region from 1962 Indo-China war. Nepal didn't officially ask to withdraw from that region as war between India and China was going on in 1962. All the Nepali maps issued after 1975 are wrong as the maps were referred from the Indian maps, without

13 Retrieved from https://myrepublica.nagariknetwork. com/news/nepal-s-new-map-covers-an-area-of-147516-sq-km-10-000-copies-being-printed/ 
field surveys. India has been using the same map since $1962 .{ }^{14}$

\section{c. Indian Strategic Interest in the North -Western Border of Nepal}

The territory in conflict is the shortest route between Indian capital New Delhi and Kailash-Mansarovar, a revered Hindu pilgrimage site in the Tibetan plateau. The link road via Lipulekh Himalayan Pass is also considered one of the shortest and most feasible trade routes between India and China. This route has been used for centuries by Hindu and Buddhist pilgrims and tourists to Kailash Mansarovar. If Lipu pass is used a tourism route for Kailsah Masarowar Yatra it will have adverse impact on revenue from tourism in Nepal. For the tri points at Limpiadhura region are very important to both China and India for trade, tourism, water, and defense.

India had deployed security forces in this region during the Indo-China war of 1962. Kalapani was regarded as a 'safe zone' for Indian troops to be stationed, as its high altitude of 20, 276 feet was "effective defense against the Chinese ${ }^{15}$. As we know that the Himalayas have various passes that connect the Gangetic region with the Tibetan plateau but the Lipulekh pass is strategically located as it is the nearest to the heart of the Indian state or National Capital Region. It is easier to monitor the highland passes with Tibet far into the distance. Due to this new Kailash Mansarovar route, a five day trek

14 Chaudhary, A. (2020, May 11). Lipulekh, Limpiyadhura, Kalapani: Trying to understand the dispute. Retrieved from https://thehimalayantimes. com/opinion/lipulekh-limpiyadhura-kalapani-tryingto-understand-the-dispute/

15 Baral, Lok Raj(Ed.). (2015) . Nepal -India Open Borders: Problems and Prospects. Vij Books India Pvt Ltd, New Delhi. will be reduced to two days of road travel thus saving six days of to and fro journey. ${ }^{16}$ Development of huge logistics and other infrastructure in Kalapani region guarded by India army proves that, Indian military wants to stay longer in that area. Although there is no any actual data on the total number of Indian Security personnel's in that part of disputed territory the number is expected to be very high. Nepal must address the genuine security and other concerns of our immediate neighbors while receiving confidence in our foreign policy dealings.

\section{d. The Role of China in the North-Western Border Dispute between Nepal-India}

India -China had agreement in 1954 that they will trade from Lipulekh. Nepal's border agreement with China in 1961 and border protocol with China in 1963 has not mentioned anything about zero number pillars. Building infrastructure in the border region is in the interest of China for utilizing the vast potential of Indian market. China is in the rapid development of the Tibet region. China believes that once it has good relations with India it can foster the connectivity via Lipulekh for fostering its business interest.

The silence of China in the dispute is also surprising. Even in 2015 during India- China agreement on Lipulekh China didn't thought of consulting it with Nepal. China has to make it position officially very clear. Nepal was not informed, nor was it a part of any talks that led to the India-China understanding when it has such a huge stake in the development of the Darchula region. ${ }^{17}$ No country has any

16 Yadav, BR. (2020, May 26). Territorial Dispute between Nepal and India. Retrieved From https:// www.prasashan.com/2020/05/26/180170/

17 Sharma, P. ( 2020 May 15). Untangling the Kalapani knot. Retrieved from https://www. nepalitimes.com/latest/untangling-the-kalapani-knot/ 
right to discuss on Nepalese territory and reach agreement on it in Nepalese absence. The border dispute is a bilateral issue between Nepal and India. China shouldn't be involved in this matter unless situation demands so. Nepal is no more "am between two boulders" rather it is vibrant bridge which is land linked.

As Indian troops are stationed in Nepal's Kalapani area near the strategic Lipulekh Pass, Nepal's interests will be drawn in case the India-China standoff escalates and the conflict extends to that area as well. There are several thousand Nepali Gurkhas in the Indian army. Their mobilization along the border may be another reason of concern for Nepal. ${ }^{18}$ China's geopolitical theory the "String of Pearls" and economic expansion and political influence through the Belt and Road Initiative (BRI) is also cultivating in South Asia, which traditionally used to be India's area of interest and influence. China is revolving South Asia as a bridge to the Indian Ocean.

\section{Nepal's Claims and Evidences}

Limpiadhura is the extreme most well defined border territorial area of Nepal. Mahakali River runs through a gorge from snowy mountains of Limpiadhura to plains. Besides Sugauli Treaty following evidences proves that the land territory illegally occupied by India is Nepalese territory.

\section{River Science}

While determining the origin of river head source or head stream is taken into consideration. Further, length of river, amount of water, depth of river etc are taken into consideration. All these factors prove that Limpiadhura is the source of Mahakali River. The river that comes from Limpiadhura is 18 Acharya, M. (2020). PRI Perspective Paper: Nepal's National Interests, Foreign Policy and Strategic Affairs. Retrieved from
$22 \mathrm{Km}$ in length and is bigger and longer in comparison to the small stream that comes from Lipulekh.

\section{Historical Maps}

Historical maps that were published by the then East India Company in 1819, 1827, $1841,1835,1846,1856$ clearly shows that Kalapani originates from Limpiadhura. After 1860s British started cartographic aggression by changing the names of the river and its source which created confusion. The political map of India published in 2017 by Survey Department of India shows that the origin of Mahakali River is Limpiadhura. India amended it in the later edition of the revised political map.

\section{Other Admissible Evidences}

The collection of maps, census report of 2018 B.S., voters list of general election of 2015 B.S., the map of Nepal issued by India in 1857 , etc. can strengthen our claim over our territories which are encroached by India. ${ }^{19}$ The Topographic Survey of Nepal should set up their own archives of maps published in Britain from 1820 to 1846 by the East India Company, the maps of 1850 and 1856 published by the Survey of India and the maps at the Geography and Map Division at the Library of Congress to bolster Nepal's claims to its territory. ${ }^{20}$

\section{Critical Dates and Evidences}

Critical dates such as 1860 should be established in our favor. Ridge cannot be border, river is the real border. Border Treaty can be only replaced by another border treaty

19 Yadav, BR. (2020, May 26). Territorial Dispute between Nepal and India. Retrieved From https:// www.prasashan.com/2020/05/26/180170/

20 Sharma, P. ( 2020 May 15). Untangling the Kalapani knot. Retrieved from https://www. nepalitimes.com/latest/untangling-the-kalapani-knot/ 
and there has not been any border Treaty so far between Nepal and India. The mark zero pillars should start from Limpiadhura (Pillar no. one starts from Tinker, Border protocol with China). Admissible evidence should be given priority. India has admitted on several occasions that Kalapani is disputed territory. In $1817 \mathrm{~J}$ Adams, a British official assigned by Governor General of British India wrote a letter to Bam Shah that Territory East to Kali River should surrender to Bam Shah. Since then, we have so far not had any border treaty with India except NAYA MUKUK SANDHI in 1860 so the main departure point we should take of article 5 of Sugali Treaty, Census until 2018 BS, revenue receipt of people those areas until 1966.

The Gazette published from Kumaon clearly indicated that Kali originates from Snowy Mountain not from fountain. Almora Gazette 1911 clearly mentioned that the fountain is erroneously supposed as the source of Kali, the true source is in Kuti Yangti. The starting pillar is one, because of non-participation of India. Pillar zero has not yet been fixed. The tradition, customs, revenue records, general election and Census till 1961 for Kuti, Nabi, Gunji are also found in Nepal. Nepal, however, had conducted elections in the area in 1959 and collected land revenue from its residents, until $1961 .{ }^{21}$

\section{Internationalizing the Issue}

We couldn't effectively exercise our sovereign authority in that area due to the presence of Indian military. A nation that has the aspiration to become a leading power someday cannot continue with the unsettled

21 Jha, HB. (2020, December 20). Addressing the Kalapani Issue between Nepal and India. Observer Research Foundation. 2019,http://www.orfonline.org/ expertspeak/addressing-the-kalapani-issue-betweennepal-and-india-59377/ borders, an un-integrated region and under exploited opportunities. ${ }^{22}$ We can use several bilateral and multilateral forums in creating favorable environment in our favor. As per article 31 of Vienna Convention on law of Treaty Secretary General legal counsel can give advice if sought. ${ }^{23}$ In case the issue goes to the Security Council, China might help for discussion. South China Sea is claimed by China on the ground of Historical title so that china might not help Nepal to contradict itself.

Bilateral consultation and agreement between the disputing parties is needed for taking any issue to ICJ. In September of 2019, India submitted its revised Declaration under Article 36 para. 2 of the Statute of the International Court of Justice (ICJ) replacing its earlier Declaration of 18 September 1974. Now with additional reservations, it will be even harder for India to be brought to the International Court of Justice on the basis of its compulsory jurisdiction, which, as explained earlier, has been rendered pointless due to India's series of reservations. For all practical purposes, the effects of India's Declaration are equivalent to never submitting to Court's compulsory jurisdiction. ${ }^{24} \mathrm{Nepal}$ also has not accepted the compulsory jurisdiction of the ICJ, to avoid the necessary litigation. So, it would be in the best interest of Nepal and India to resolve the border dispute amicably. Good offices of Secretary General can be used to resolve the issue.

22 Jaishankar,S. (2020) . The India way.Harper Collins Publishers Inidia.

23 Basnyat, B. (2020 June 2). Geo-politics of the Himalayas. Retrieved from https://www.spotlightnepal. com/2020/06/02/geo-politics-himalayas/

24 Retrieved from https://juristpanel.com/indiasmodified-declaration-on-the-jurisdiction-of-theinternational-court-of-justice/ 


\section{Conducting Effective Diplomacy}

Foreign policy should be smart and pragmatic by analyzing the real ground of regional and global context rather than being guided by the emotion. ${ }^{25}$ Nepal should take geo politics as opportunity and if we can't manage it well it will become burden to us. Need of robust diplomacy to utilize funds on border connectivity, and missing links that are international and regional global project i.e. BRICS bank, OBOR, Investment Bank etc. ${ }^{26}$ Geo-economics, geo-strategies are the burning issue in South Asia these days. Nepal is the closest neighbor of India. India's success and rise in the global politics lies in the strength of its neighbor. Problem free, developed and stable neighbor is always at the India strength. The world of twenty-first century is of India and china. Careful dealing with these countries requires great diplomatic maturity.

Harmonious relation between India and China is in the interest of Nepal. In 2009, the then Indian external affairs minister, Pranab Mukherjee, on a visit to Nepal said that both sides had "agreed to resolve the long standing border disputes between the two countries at various places, including Kalapani and Susta through further discussions." ${ }^{27}$ In a 1998 interview with Kantipur newspaper, then Indian Ambassador to Nepal KV Rajan had said that India was ready to give up its claim on Kalapani if Nepal could persuade it to do so based on solid evidence. ${ }^{28}$ Government of

25 Ibid at 23 .

26 Ibid at 23.

27 Bose, Tapan Kumar. (2020 May 26). The Kalapani Imbroglio: Has India Pushed Nepal Too Far?. Retrieved from https://thewire.in/south-asia/kalapani-india-nepal 28 Bhattarai, Kamal Dev. (2020 August 8). The evolution of Kalapani border dispute between Nepal and India. Retrieved from https://theannapurnaexpress. com/news/the-evolution-of-kalapani-border-dispute-
Nepal had expressed its disagreement in 2015 through separate diplomatic notes addressed to the governments of both India and China when the two sides agreed to include Lipu Lekh Pass as a bilateral trade route without Nepal's consent in the Joint Statement issued on 15 May 2015 during the official visit of the Prime Minister of India to China. ${ }^{29} \mathrm{Nepal}$ should ask India to withdraw any map that alters the status quo unilaterally until the disputed boundary is resolved bilaterally. The government of Nepal shouldn't accept Lipulekh as tri-junction between Nepal, India and China. It will be finalized only after Nepal and India agree for border demarcation. ${ }^{30}$ India's refusal to sit for a bilateral dialogue in Nepal's request has undermined the traditionally-friendly relations between the two countries, bringing the relations to an alltime low. ${ }^{31}$

\section{Efforts Made so far to Solve Border Dispute $^{32}$}

1. In the 1980s, the two sides set up the Joint Technical Level Boundary Working Group to delineate the boundary. The group demarcated everything except Kalapani and Susta area. 2. Officially, Nepal brought the issue of Kalapani before India in 1998. Both sides agreed to demarcate the outstanding areas (including Kalapani) by 2002 at the prime ministerial level talk held in 2000. But that has not happened yet.

Kalapani was again discussed in Kathmandu between-nepal-and-india-2747

29 Retrieved from https://mofa.gov.np/press-releaseregarding-lipu-lekh/

30 Retrieved from https://thehimalayantimes.com/ nepal/kalapani-nepali-territory-government/

31 Acharya, M. (2020) . PRI Perspective Paper: Nepal's National Interests, Foreign Policy and Strategic Affairs. Retrieved from

32 Yadav, BR. (2020, May 26). Territorial Dispute between Nepal and India. Retrieved From https:// www.prasashan.com/2020/05/26/180170/ 
during the fifth meeting of the Joint Working Group on the India-Nepal Boundary, on 17 July 1998. Point seven of the meeting minutes reads: "The two sides continued their useful exchange of the views on the examination of the relevant facts relating to the demarcation of the boundary alignment in the western sector including Kalapani area. The Nepalese side stated that the boundary between Nepal and India in the area was the Kali River as explicitly lay down in article 5 of the treaty of Segowlee and therefore sought clarification from India side..." ${ }^{33}$ Likewise, in 1999, foreign minister Jaswant Singh, on a visit to Nepal, said India was prepared toresolve the Kalapani issue through negotiations. Again, nothing happened. Despite several efforts from Nepalese side the border dispute of the North-western Nepal is not solved yet.

\section{Alternatives for Resolving the Dispute}

Dialogue should be done at the highest political level. When there is good relationship at the political level exchange of land can be done. Land swap, dedicated transit route via Bangladesh, Joint sovereignty of the disputed area could be other viable options. Trilateral development area via (Investment zone) can be developed in case India accepts Nepalese sovereignty over the disputed territory. Border protocol should be signed with both neighbors. GPS and electronic mapping should be started at the earliest. Consultation at the political level should go on. Multi stakeholder in coordination at home is the need of the hour.

Diaspora engagements and interaction in our favor for this issue will be in Nepal's favor. India should revise its controversial map and accept the map published by Nepal and start vacating once the agreement is reached.

33 Ibid at 29 .
Lease agreement of the disputed territory could be another viable solution.

Civilization strength of both Nepal and India should mutual trust and understanding in the sensitive issues. Political instability, double standard, confusion, and unpredictability of political leader is making situation of Nepal more miserable. Further the effectiveness of foreign policy doesn't lie on populism, opportunism and jingoism or nationalism, but should be guided and run by ground .34“"Border diplomacy" has become urgent to curb illicit activities of drug, arms trade and human trafficking and non-traditional security threats. ${ }^{35}$ Having border dispute with the friendly neighbor whose people have sacrificed their life for her is not in the favor of India. Nepali citizens belonging to that area depend on India for daily essentials, jobs, including medicine and educational facilities.

Opportunities like Nepal can be transit economy, can be transit provider, can be the dynamic bridge, and can be land linked but the opportunities may not be there forever, we might lose that if we don't tap that on time. ${ }^{36}$

\section{Conclusion}

Border issues are most sensitive and emotionally charged issues. We need to be more articulate and forward looking with clarity in our thoughts, consistency in our

34 Asian Institute of Diplomacy and International Affairs (AIDIA) (2016). Revisiting Nepal Foreign Policy on Contemporary Global Power Structure. Retrieved from file://C:/Users/lenovo/Downloads/AIDIA.pdf 35 Institute of Foreign Affairs. (2012). A Report on Emerging Challenges of Nepal's Foreign Policy National Level Seminars. Retrieved from file:///G:/ Kalapani/A-Report-on-FES-Seminar_print-copy.pdf 36 Asian Institute of Diplomacy and International Affairs (AIDIA) (2016). Revisiting Nepal Foreign Policy on Contemporary Global Power Structure. Retrieved from file://C:/Users/lenovo/Downloads/AIDIA.pdf 
actions, coherence in our activities, dynamic in analysis of facts, deeper understanding of issues, prudent in behaviors, diplomatic in dealings for the promotion and protection of our territorial sovereignty. We cannot afford to choose the neighbors. An expert group was formed by the government of Nepal for the collection of evidences of the disputed border region which has submitted its report. NepalChina under the cooperation framework of Trans Himalayan Multi Dimensional Connectivity Network. We should avoid populist posturing and abide by principled policy. Geographic dictation of Nepal has pressurized Nepal. Geographical vicinity and cultural affinity has forced Nepal to become close to India. We have to redefine and redesign our relationship with India. During Integrated Development of Mahakali River we shouldn't have signed that Treaty without finding the source Mahakali River. We failed to do so. Further construction in the disputed territory should be immediately brought to halt. Both countries should walk extra miles in erasing the past bitter experience and move to establish dynamic relationships. Infrastructure bottlenecks at the border area should be removed. Creative and constructive approaches to deal with such sensitive issues with clear and close understanding of the issues require patience. We should adopt autonomy in decision making. According to Schedule 5 of the Constitution of Nepal 2015 International border and International Boundary River falls in the federal jurisdiction. So redlines should be drawn for the provinces not to carry out any activities related to foreign affairs.

\section{Recommendations}

We have to engage with all while also ensuring that we do not get caught in the entanglement. This requires clarity, consistency, wider vision, deeper analysis, clear articulation, profound and continuous communication and the capacity to look beyond the present. ${ }^{37}$ Nepal should be building bridge between two giant neighbors and across the region.

Periodic monitoring of the border and replacement of the lost or damaged border pillars should be on time. Encroachment of no man's land and frictions at the border point should be stopped. Revamping of the border cells at the District Administration office should be done. Put in place robust border surveillance and intelligence mechanism to check smuggling and the movement of criminals across the borders as well as explore the possibility of managing the border without causing difficulties to the general public. ${ }^{38}$

Having very complicated bilateral relations and difficult diplomatic history managing more powerful nations requires diplomatic sharpness. We cannot change our neighbors but we can change our policies that best suits our soil. A single voice with concerted action backed by decisive strategies and national consensus will help to preserve our national interest.

National security institutions looking after the border security should be strengthened. Nepal should not join any military and security blocks and should not compromise the principles of NAM. Military diplomacy can be streamlined to promote our national interest. Historically, Nepal has been entrepot between India and China and we should revive that

37 Acharya, Gyan Chandra. (2020) . Need for Dynamism in Nepal's foreign Relations, page .19. AFCAN Review, (Vol.1)19.

38 High level Report on Foreign policy of Nepal, 2006 . 
significance for our economic advantage. We should adopt connectivity driven strategies and approaches for economic integration and for our economic growth.

We should involve huge Nepali Diaspora in India for creating favorable environment in our favor. Government should increase investment in strategic affairs including creating strategic and institutions related to border studies. In line with national security policy Nepal should adopt a comprehensive National security strategy. Strategic location of Nepal should be best utilized for our benefit without being unnecessary dragged into big power rivalries.

Confidence building measures let the problem keep at standstill and prevent from further escalation. We must improve our state capacity to govern this beautiful land. Equality, openness, mutual respect, trusts are the hallmarks while resolving the outstanding issue.

Survival and independence is central to our existence. Amid the incessant, underestimation, negligence and discarding our diplomatic requests, Government of Nepal has issued first ever Political/Administrative Map; with the reference of Article 5 of Sugauli Treaty 1816, which clearly stated that East to Kali river would be Nepal's sovereign territory since then. The issue couldn't be settled through technical and diplomatic level. It should be cleared through the highest political level. Streets protests, media propaganda and political slogans will only complicate the matter.

We are fully convinced that it is our territory. There has been unanimity at home in this fact. So let's not delay to seize the opportunity. Not only at the time of crisis rather at the favorable environment should we seize the opportunity. War is never a preference in Nepalese history and we can't afford it as well.

Dialogue and diplomacy through confidence building measures by single voice at home is in the best interest to resolve outstanding border at NorthWestern border of Nepal.

\section{References}

High level Report on Foreign policy of Nepal, 2006.

The Constitution of Nepal, 2015

Sugauli Treaty 1816

Subedi, S. (2005). Dynamics of Foreign Policy and Law: A Study of Indo-Nepal Relations: Oxford Publications.

Acharya, G. C. (2020). Need for Dynamism in Nepal's foreign Relations, page.19. AFCAN Review, (Vol.1)19.

Bhattarai, K. D. (2020 August 8). The evolution of Kalapani border dispute between Nepal and India. Retrieved from https://theannapurnaexpress.com/news/ the-evolution-of-kalapani-border-disputebetween-nepal-and-india-2747

Yadav, B. R. (2020, May 26). Territorial Dispute between Nepal and India. Retrieved From https://www.prasashan. com/2020/05/26/180170/

Asian Institute of Diplomacy and International Affairs (AIDIA) (2016). Revisiting Nepal Foreign Policy on Contemporary Global Power Structure. Retrieved from file:///C:/ Users/lenovo/Downloads/AIDIA.pdf 
Bose, T. K. (2020 May 26) . The Kalapani Imbroglio: Has India Pushed Nepal Too Far? Retrieved from https://thewire.in/south-asia/ kalapani-india-nepal

Baral, L. R. (Ed.). (2015). Nepal -India Open Borders: Problems and Prospects. Vij Books India Pvt Ltd, New Delhi.

Acharya, M. (2020). PRI Perspective Paper: Nepal's National Interests, Foreign Policy and Strategic Affairs. Retrieved from

Sharma, P. (2020 May 15). Untangling the Kalapani knot. Retrieved from https:// www.nepalitimes.com/latest/untangling-thekalapani-knot/

Jaishankar, S. (2020) . The India way. Harper Collins Publishers Inidia.

Basnyat, B. (2020 June 2). Geo-politics of the Himalayas. Retrieved from https://www. spotlightnepal.com/2020/06/02/geo-politicshimalayas/

Rai, A. B. (Ed. 2010). Nepals foreign policy: Historical outline and Future Perspective International Relations and Foreign Affairs: Sopan Monthly

Institute of Foreign Affairs. (2012). A Report on Emerging Challenges of Nepal's Foreign Policy National Level Seminars. Retrieved from file://G:/Kalapani/A-Report-on-FESSeminar_print-copy.pdf

Newspaper Articles and websites

Retrieved from https://mofa.gov.np/press-releaseregarding-lipu-lekh/

Retrieved from https://thehimalayantimes.com/ nepal/kalapani-nepali-territory- government/
Sharma, P. (2020 May 15). Untangling the Kalapani knot. Retrieved from https:// www.nepalitimes.com/latest/untangling-thekalapani-knot/

Retrieved from https://mofa.gov.np/press-releaseregarding-lipu-lekh/.

Chaudhary, A. (2020, May 11). Lipulekh, Limpiyadhura, Kalapani: Trying to understand the dispute. Retrieved from https://thehimalayantimes.com/opinion/ lipulekh-limpiyadhura-kalapani-trying-tounderstand-the-dispute/

https://www.mohp. gov.np/downloads/ Constitution $\% 20$ of $\% 20 \mathrm{Nepal} \% 202072$ full_ english.pdf

Retrieved from https://mofa.gov.np/press-releaseregarding-lipu-lekh/.

National Secuity Policy 2016, section 1.2.2, Page 3. Retrieved from Law Books Management Board, Babarmahal Kathmandu.

Basnyat, B. (2020). Nepal on A Larger Geopolitical Modification In The Himalayas. Retrieved From https://www.spotlightnepal. com/2020/06/14/nepal-larger-geopoliticalmodification-himalayas/

Koirala, N. (2020, June 4). LimpiadhuraLipulekh-Kalapani dispute. The Kathamandu Post. Retrieved from https://kathmandupost. com/columns/2020/06/04/limpiyadhurakalapani-lipulekh-dispute 